\title{
Recent research and resources on: Open access publishing
}

(compiled November 09)

\section{Janet Clapton}

\section{What is this column?}

This is an occasional column, intended to provide a selection of recently published articles and other resources on a specific topic.

The selection is a 'taster' rather than being exhaustive, and is not a comprehensive review of evidence on the topic.

The aim is to encourage LIS practitioners' current awareness: delve into the resources and links and see where it takes you!

\section{How was material gathered?}

Material was gathered by using approaches such as:

1. Searching Tic Tocs Table of Contents service to find RSS feeds on relevant journals: see www.tictocs.ac.uk/

2. Using a feed reader such as Google Reader to process and search within the RSS feeds www.google.com/reader

3. Searching across CILIP resources for members: see www.cilip.org.uk Member resources (requires member login).

4. Drawing on LIRG website links: see www.cilip.org.uk/specialinterestgroups/bysubject/research/links

Generally the current year's issues of journals' tables of contents are used, but slightly older material in repositories is also included.

\section{Janet Clapton}

Janet Clapton is Project Information Manager at the Social Care Institute for Excellence.

Email: janet.clapton@scie.org.uk

Received 13 November 2009

Accepted 04 December 2009 


\section{What is "Open Access?"}

"Open Access" is a model of research publication where material is freely available on the internet. There is debate around the impact and utility of this type of approach.

Wikipedia gives a detailed definition and discussion: http://en.wikipedia.org/wiki/Open_access

See also CILIP Information Team's webpage on open access journals: www.cilip.org.uk/informationadvice/practicalguides/openaccess/

\section{Suggested resources}

Directory of Open Access Journals www.doaj.org/ including 97 journals listed under Library and Information Science

OpenJ-Gate www.openj-gate.org including 79 journals listed under Library and Information Sciences

Registry of Open Access Repositories http://roar.eprints.org/

The Open Access Directory http://oad.simmons.edu/oadwiki/Main Page

Budapest Open Access Initiative http://www.soros.org/openaccess

This loose collaboration is committed to promoting the open access publication of research, within a diversity of approaches.

Biomed Central www.biomedcentral.com/ Biomed Central is a major open access publisher.

\section{Selected items from recent journals}

Wong, Yi-Ling (San Jose State University) (2009). Open access in libraries. Library Student Journal, 4, January 2009.

The journal is written for and by Masters degree LIS students. This paper, from the latest issue, is a critical discussion of the general background and basic concepts of open access, as well as its current developments. (Full text access available via journal home page www.librarystudentjournal.org/index.php/lsj).

Waaijers, Leo. (2009) Publish and cherish with non-proprietary peer review Systems. Ariadne, 59.

The author defines non-proprietary peer review as "peer review systems that do not require the assignment of copyright to the organiser of the peer review i.e. the publisher". (Full text accessible via journal home page at www.ariadne.ac.uk/ ).

Joint, N. (2009). The Antaeus column: does the 'open access' advantage exist? A librarian's perspective. Library Review, 58(7), 477-481.

Discussion paper on running and evaluating open access repositories. (Full text accessible via CILIP member resources).

Joint, N. (2009). The "author pays" model of access and UK-wide information strategy. Library Review, 58(9), 630-637.

Comment on the potential for development of "author pays" open access (APOA) 
research publication in the UK. (Full text accessible via CILIP member resources).

Greyson, Devon; Morgan, Steven; Hanley, Gillian; Wahyuni, Desy. (2009). Open access archiving and article citations within health services and policy research. Journal of the Canadian Health Libraries Association, 30(2), 51-58.

Study showing that open access archived articles were more likely to be cited at least once, and once cited, were cited up to $29 \%$ more than non-open access articles. (Full text freely available via journal home page http://pubservices.nrccnrc.ca/rp-ps/journalDetail.jsp?.jcode=jchla\&lang=eng).

\section{Podcasts}

Found via CILIP Podcasts (includes content from other providers) http://communities.cilip.org.uk/blogs/podcasts/default.aspx on CILIP Communities http://communities.cilip.org.uk/.

See 16 February 2009 LISTen: An LISNews.org Podcast -- Episode \#60. Dr Stevan Harnad talks about Open Access in the US.

\section{Conferences}

Open Access is the theme of IFLA's 2010 conference - see www.ifla.org/en/annual-conference

See also the Events section of the Open Access Directory http://oad.simmons.edu/oadwiki/Events 